\title{
SNOW MOLD FUNGUS, TYPHULA ISHIKARIENSIS GROUP III, IN ARC- TIC NORWAY CAN GROW AT A SUB-LETHAL TEMPERATURE AFTER FREEZING STRESS AND DURING FLOODING.
}

\author{
T. Hoshino, A.M. Tronsmo \& I. Yumoto
}

Hoshino, T., Tronsmo, A.M. \& Yumoto, I. 2008. Snow mold fungus, Typhula ishikariensis group III, in Arctic Norway can grow at a sub-lethal temperature after freezing stress and during flooding. - Sommerfeltia 31: 125-131. ISBN 82-7420-045-4. ISSN 0800-6865.

Isolates of the snow mold fungus Typhula ishikariensis group III, which is predominant in Finnmark (northern Norway) and Svalbard, are more resistant to freezing stress than group I isolates from the southern part of Norway. Group III isolates showed irregular growth on potato dextrose agar (PDA) plates when subjected to heat stress at $10^{\circ} \mathrm{C}$. However, group III isolates showed relatively good growth on PDA at $10^{\circ} \mathrm{C}$ after freezing treatment. The optimal temperatures for mycelial growth were $5^{\circ} \mathrm{C}$ on PDA and $10^{\circ} \mathrm{C}$ in potato dextrose broth (PDB), and group III isolates showed normal mycelial growth at $10^{\circ} \mathrm{C}$ in PDB. Mycelium of group III isolates cultivated in water poured into PDA plates, and normal hyphal extension was observed only in the liquid media. Hyphal growth became irregular when mycelia had extended above the surface of the liquid media. These results suggested that group III isolates can grow at a sub-lethal temperature after freezing stress and during flooding. Soil freezing and thawing occurs regularly in the Arctic, and physiological characteristics of group III isolates are well adapted to climatic conditions in the Arctic.

Keywords: group III, Finnmark, flooding, freezing stress, snow mold, Svalbard, Typhula ishikariensis

Tamotsu Hoshino, Research Institute of Genome-based Biofactory, National Institute of Advanced Industrial Science and Technology (AIST), 2-17-2-1, Tsukisamu-higashi, Toyohira-ku, Sapporo 0628517, Japan, and Division of Biological Sciences, Graduate School of Science, Hokkaido University, N10 W8, Kita-ku, Sapporo 060-0810, Japan. Phone: +81 11857 8475, Fax: +81 11857 8980, e-mail: tamotsu.hoshino@aist.go.jp

Anne Marte Tronsmo, The Norwegian Crop Research Institute, Høgskoleveien 7, N-1432, As, Norway

Isao Yumoto, Research Institute of Genome-based Biofactory, National Institute of Advanced Industrial Science and Technology (AIST), 2-17-2-1, Tsukisamu-higashi, Toyohira-ku, Sapporo 062-8517, Japan, and Division of Applied Bioscience, Graduate School of Agriculture, Hokkaido University, N9 W9, Kita-ku, Sapporo 060-8589, Japan 


\section{INTRODUCTION}

Snow mold fungi are psychrophilic or psychrotrophic fungal pathogens of perennial grasses and winter cereals in the Northern Hemisphere (Hsiang et al. 1999). Microdochium nivale (Fr.) Samuels \& Hallett, Sclerotinia borealis Bubák \& Vleugel, Typhula incarnata Lasch ex. Fr. and T. ishikariensis Imai are typical snow mold fungi found in Nordic countries, including Denmark (where M. nivale and T. incarnata have been found: Welling \& Jensen 1970), the Faroe Islands (where M. nivale and T. incarnata have been found: Hoshino et al. 2004a), Finland (Jamalainen 1949, 1957), Greenland (where S. borealis, T. incarnata and T. ishikariensis have been found: Hoshino et al. 2006), Iceland (where M. nivale, T. incarnata and T. ishikariensis have been found: Kristinsson \& Guðleifsson 1976, Hoshino et al. 2004b), Kola Peninsula in the Russian Arctic (Petrov 1983), Norway (Årsvoll 1975) including Svalbard (where T. ishikariensis and S. borealis have been found: Hoshino et al. 2003) and Sweden (Ekstrand 1955).

In T. ishikariensis, several infraspecific taxa occur adapted to different winter climates (Matsumoto 1992, 1995). Typhula ishikariensis in Norway has been classified into three groups (group I, II and III) by Matsumoto \& Tronsmo (1995) according to genetic relationships and cultural characteristics. Isolates of group I and II grow normally at $10^{\circ} \mathrm{C}$ on potato dextrose agar (PDA) plates, whereas isolates of group III are characterized by irregular growth on PDA at $10^{\circ} \mathrm{C}$ (Matsumoto \& Tronsmo 1995, Hoshino et al. 1997). These three groups also have different distribution patterns: group I and II are predominant in the southern and middle parts of Norway, while group III is most prevalent in the north (Matsumoto et al. 1996) including Svalbard (Hoshino et al. 2003) and Greenland (Hoshino et al. 2006). In northern Norway (Finnmark), grasses and wheat are killed due to severe subzero temperatures after intermittent snow melt during winter (Årsvoll 1973). This distribution pattern indicates that group III strains are more adapted than the other two groups to lower temperatures. We have already reported that freezing resistance is one of the important factors correlated with the geographical distribution of T. ishikariensis in northern Norway (Hoshino et al. 1998) and Siberia (Hoshino et al. 2001).

Group III strains seem to be highly adapted to the snow cover environment in the Arctic, where soil often freezes in mid-winter and humidity is high in early spring. However, most studies on physiological characteristics of snow mold fungi, including T. ishikariensis, were carried out in artificial conditions such as on PDA plates, which does not reflect the environmental conditions under the snow cover. In this paper, we present the results of experiments in which $T$. ishikariensis group III strain was cultured on PDA after freezing stress and cultured in liquid media reflecting a high humidity condition.

\section{MATERIAL AND METHODS}

\section{Fungal strains}

Group III strain 4-3-3 was used in the experiments. The 4-3-3 isolate was collected from timothy (Phleum pratense) in Finnmark, northern Norway in 1992 (Matsumoto \& Tronsmo 1995). The cultures was maintained on potato dextrose agar (PDA) slants at $4^{\circ} \mathrm{C}$. 


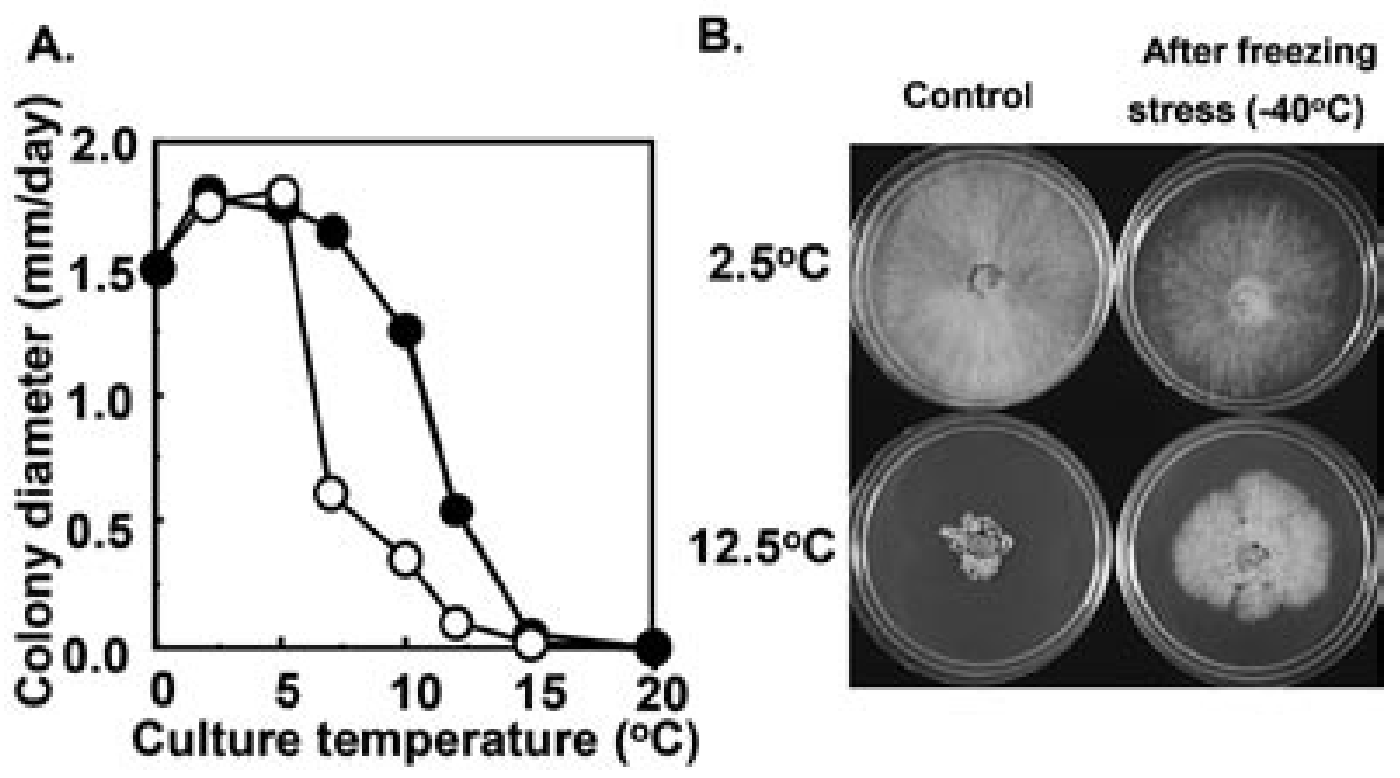

Fig. 1. Effect of freezing stress on mycelial growth temperature of Typhula ishikariensis group III strain 4-3-3 on potato dextrose agar plates. A. mycelial growth rate. Open circles are control (no freezing treatment). Closed circles are after freezing treatment. B. Macromorphologies on potato dextrose agar plates.

\section{Mycelial regrowth on PDA after freezing stress}

Mycelial discs of $5 \mathrm{~mm}$ in diameter (cut from the margin of an actively growing colony) were placed on PDA plates of $2.5 \mathrm{~cm}$ in diameter and frozen to $-40^{\circ} \mathrm{C}$ in a programmed freezer at a cooling rate of $20^{\circ} \mathrm{C} / \mathrm{h}$ (Hoshino et al. 1998, 2001). After freezing, the mycelial discs were thawed at $2^{\circ} \mathrm{C}$ for 16 $\mathrm{h}$, and each disc was transferred to a fresh PDA plate of $9 \mathrm{~cm}$ in diameter and incubated at 0 to $20^{\circ} \mathrm{C}$ in duplicate. After 1, 2 and 3 weeks of incubation, the colony diameters were measured. The linear mycelial growth rate per day was calculated after the initial lag period.

\section{Mycelial growth in liquid medium and sterilized water poured into PDA plates}

Five mycelial discs of $5 \mathrm{~mm}$ in diameter (cut from the margin of an actively growing colony) were used to inoculate $100 \mathrm{ml}$ of potato dextrose broth (PDB) and liquid cultures were incubated for 1 month at $0-20^{\circ} \mathrm{C}$ with vigorous shaking. The mycelium was collected by filtration and washed 3 times in cold water, and mycelial weight was estimated as wet weight.

Mycelial discs of $5 \mathrm{~mm}$ in diameter (cut from the margin of an actively growing colony) were inoculated onto fresh PDA plates of $9 \mathrm{~cm}$ in diameter and incubated at $2^{\circ} \mathrm{C}$ for 3 days. PDA plates on which hyphal extension were observed, was sterile water poured into the plates as Fig. 3 shows and incubated at 0 and $10^{\circ} \mathrm{C}$ for 3 weeks in duplicate. 


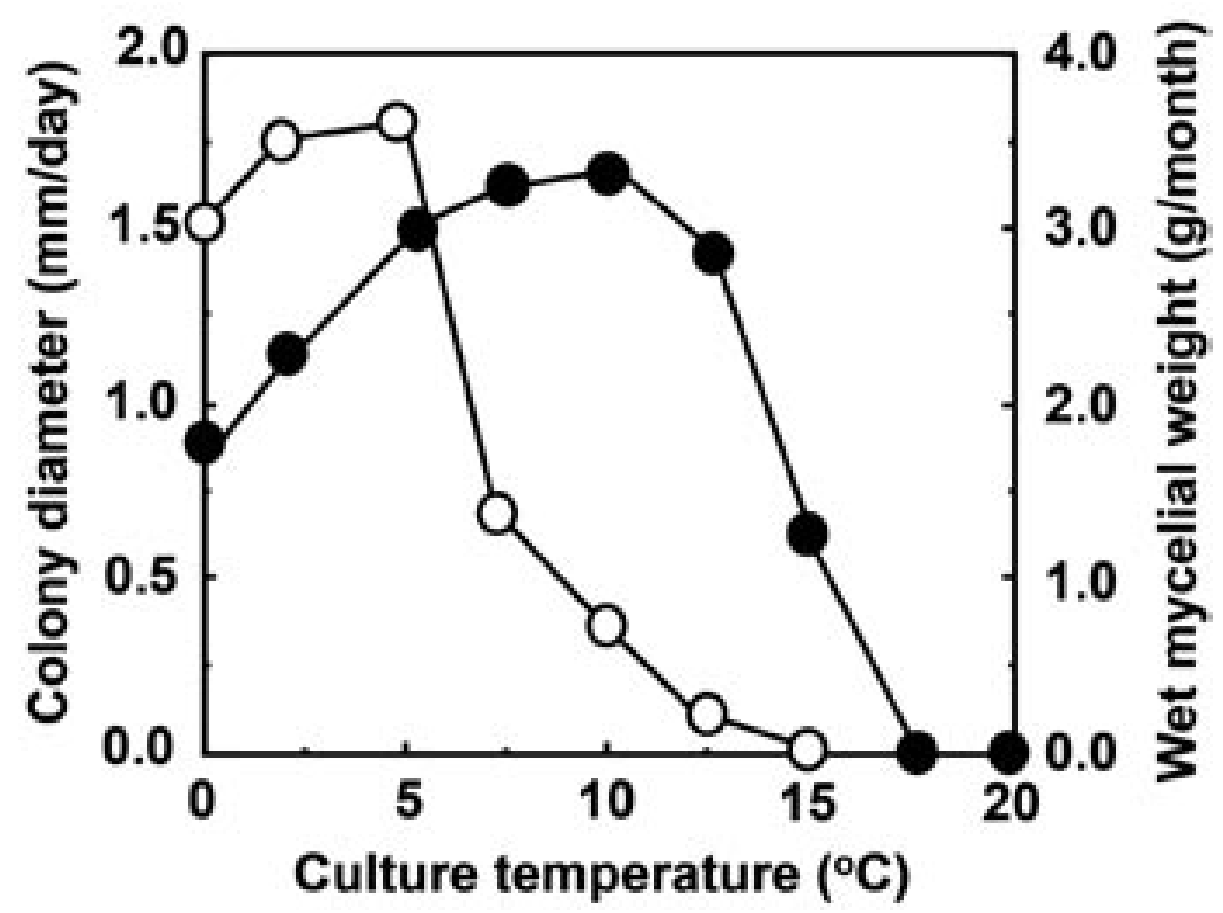

Fig. 2. Mycelial growth rate of Typhula ishikariensis group III strain 4-3-3 on potato dextrose agar plates (open circles) and in potato dextrose broth (closed circles) at various culture temperatures.

\section{RESULTS AND DISCUSSION}

Effect of freezing stress on mycelial growth of group III strains on PDA at various cultivation temperatures

The optimal growth temperature of a group III strain 4-3-3 from Finnmark was $5^{\circ} \mathrm{C}$, and hyphal extension of the strain was inhibited from $7.5^{\circ} \mathrm{C}$ on PDA plates. Fungal colonies of strain 4-3-3 showed irregular shapes in this cultural condition (Fig. 1B, same results recorded by Matsumoto et al. 1996, Hoshino et al. 1997). There was no difference between mycelial growth rate on PDA plates in control (without the freezing stress) and with freezing treatment. However, after freezing stress mycelia showed a higher growth rate compared to before the freezing treatment (control). Macromorphologies were also improved by the freezing treatment. Typhula ishikariensis is a typical psychrophilic fungus that can not grow at temperatures above $20^{\circ} \mathrm{C}$. The freezing stress was accelerated in mycelial growth rate on PDA plates at 7.5 to $12.5^{\circ} \mathrm{C}$, but freezing treatment did not change the maximal growth temperature (strain 4-3-3 did not above $15^{\circ} \mathrm{C}$ ). We also obtained the same results from other group III strains from Finnmark, Svalbard and Greenland (data not shown).

In eucaryotic microorganisms such as yeast, many studies have shown that temperature stress (treatment at temperatures higher or lower than the growth temperature) induced many heat-shock 


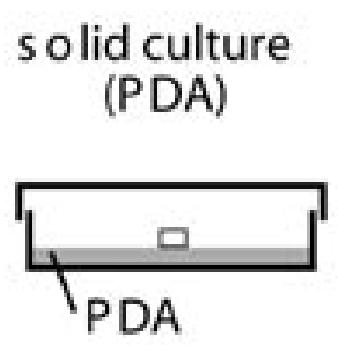

\section{solid/liquid culture (PDA+water)}
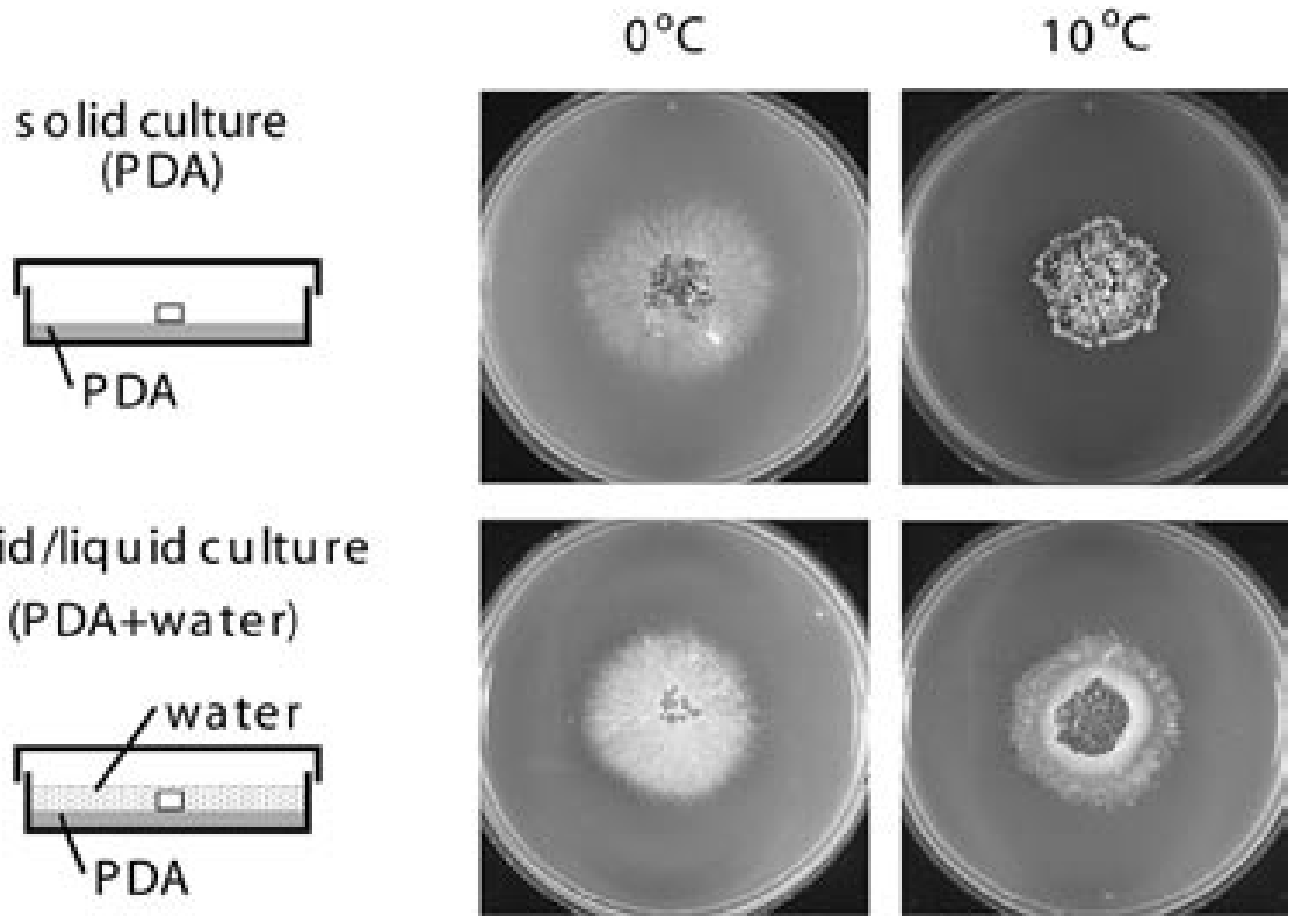

Fig. 3. Macromorphologies of Typhula ishikariensis group III strain 4-3-3 on sterilized water poured into potato dextrose agar plates.

genes and proteins. Some of these proteins are related to cell growth and maintenance. The freezing stress of $T$. ishikariensis group III probably also induced expressions of heat-shock proteins that support mycelial growth at sub-lethal high temperatures $\left(10-12.5^{\circ} \mathrm{C}\right)$.

\section{Mycelial growth in liquid medium and sterilized water poured into PDA plates}

Figure 2 shows the mycelial growth rates on PDA plates and in PDB liquid culture at various temperatures. Mycelial growth rate of group III on PDA was inhibited from $7.5^{\circ} \mathrm{C}$. However, the same fungus had an optimal growth temperature at $10^{\circ} \mathrm{C}$ and could grow at $15^{\circ} \mathrm{C}$ in PDB. Mycelial growth of fungal discs after freezing stress did not differ from the mycelial growth rate of the control (data not shown).

Figure 3 shows fungal colonies of strain 4-3-3 on PDA plates and PDA plates piled up in sterilized water. Normal hyphal extension was observed only in sterilized water at $10^{\circ} \mathrm{C}$. We also obtained the same results when 4-3-3 strain that was cultured on PDA plates piled up in PDB. Some of the fungal colonies above the surface of the liquid media became brown and showed irregular colony morphology.

Mycelia of T. ishikariensis grow only under a snow cover in which high humidity is maintained in the natural environment. Our results suggested that group III strains have adapted to the environmental conditions under the snow cover. 


\section{ACKNOWLEDGMENTS}

We thank The Research Council of Norway and Agency of Industrial Science and Technology (AIST) for financial support of our research project.

\section{REFERENCES}

Ekstrand, H. 1955. Höstsädens och vallgräsens överwintering. - St. Växtskyddsanst. Medd. 67: 1125.

Hoshino, T., Tronsmo, A.M., Matsumoto, N., Ohgiya, S., \& Ishizaki, K. 1997. Effects of temperature on growth and intracellular proteins of Norwegian Typhula ishikariensis isolates. - Acta agric. scand. B Soil Pl. Sci. 47: 185-189.

Hoshino, T., Tronsmo, A.M., Matsumoto, N., Araki, T., Georges, F., Goda, T., Ohgiya S., \& Ishizaki, K. 1998. Freezing resistance among isolates of psychrophilic fungus, Typhula ishikariensis, from Norway. - Proc. NIPR Symp. pol. Biol. 11: 112-118.

Hoshino, T., Tkachenko, O.B., Tronsmo, A.M., Kawakami, A., Morita, N., Ohgiya, S., Ishizaki, K. \& Matsumoto, N. 2001. Temperature sensitivity and freezing resistance among isolates of Typhula ishikariensis from Russia. - Búuísindi 14: 61-65.

Hoshino, T., Saito, I. \& Tronsmo, A.M. 2003. Two new snow mold fungi from Svalbard. - Lidia 6: 30-32.

Hoshino, T., Gaad, M., Kiriaki, M. \& Yumoto, I. 2004a. A snow mold fungus, Typhula incarnata from the Faroe Islands. - Acta bot. isl. 14: 71-76.

Hoshino, T., Kiriaki, M., Yumoto, I \& Kawakami, A. 2004b. Genetic and biological characteristics of Typhula ishikariensis from Northern Iceland. - Acta bot. isl. 14: 59-70.

Hoshino, T., Saito, I., Yumoto, I., \& Tronsmo, A.M. 2006. New findings of snow mold fungi from Greenland. - Medd. Grønland, Biosci. 56: 89-94.

Hsiang, T., Matsumoto, N. \& Millett, S.M. 1999. Biology and management of Typhula snow molds of turfgrass. - Pl. Dis. 83: 788-798.

Jamalainen, E.A. 1949. Overwintering of Gramineae-plants and parasitic fungi. I. Sclerotinia borealis Bubák \& Vleugel. - J. sci. agric. Soc. Finl. 21: 125-142.

Jamalainen, E.A. 1957. Overwintering of Gramineae-plants and parasitic fungi. II. On the Typhula sp-.fungi in Finland. - J. sci. agric. Soc. Fin. 29: 75-81.

Kristinsson, H. \& Guðleifsson, B.E. 1976. The activity of low temperature fungi under the snow cover in Iceland. - Acta bot. isl. 4: 44-57.

Matsumoto, N. 1992. Evolutionary ecology of the pathogenic species of Typhula. - Trans. mycol. Soc. Jpn 33: 269-285.

Matsumoto, N. 1995. Ecological adaptations of low temperature plant pathogenic fungi to diverse winter climates. - Can. J. Pl. Pathol. 16: 237-240.

Matsumoto, N. \& Tronsmo, A.M. 1995. Population structure of Typhula ishikariensis in meadows and pastures in Norway. - Acta agric. scand. B Soil Pl. Sci. 45: 197-201.

Matsumoto, N., Tronsmo, A.M. \& Shimanuki, T. 1996. Genetic and biological characteristics of Typhula ishikariensis isolates from Norway. - Eur. J. Pl. Pathol. 102: 431-439.

Petrov, V.F. 1983. Pathogenic microflora of root growth in perennial grasses in Khibiny (in Russian). - Bull. appl. bot. Genet. P1. Breed. 82: 38-45. 
Welling, V.B. \& Jensen, A. 1970. Sneskimmel in grœsplœner 1969/70. - St. PlPathol. Forsøg. 451: 45-50.

Årsvoll, K. 1973. Winter damage in Norwegian grasslands 1968-1971. - Meld. Norg. LandbrHøgsk. 52: 3: $1-21$.

Årsvoll, K. 1975. Fungi causing winter damage on cultivated grasses in Norway. - Meld. Norg. LandbrHøgsk. 54: 9: 1-49. 